\title{
Poverty Alleviation and Microfinance in post-Soviet Central Asia
}

\author{
Assoc. Prof. Dr. Heiko Fritz (Linnaeus University Växjö, Sweden)
}

\begin{abstract}
Microfinance has played an important role in poverty alleviation throughout the developing world. Though some Central Asian countries are blessed with abundant natural resources, uneven income distribution and poverty are prevalent. Microfinance, however, has not been much in the public discussion in the region. The aim of this paper is to take stock of microfinance in Central Asia; to review recent developments in the context of the global development in the sector; to assess the regulatory and supervisory environment; and to identify untapped potential with respect to the future development of the industry.
\end{abstract}

\section{Introduction}

Microfinance has become a major pillar of strategies for global poverty reduction since Muhammad Yunus pioneered joint liability group lending in the early 1980s in Bangladesh, an innovative institutional setting to reduce transaction cost in small scale lending. In the meantime microfinance has become a mature industry. International donors and commercial investors channel significant funds to microfinance institutions (MFI) in developing countries. The scope of financial services supplied by MFI has broadened beyond microcredit including savings products, microinsurance and leasing. An increasing number of MFI operate profitably. Initially an informal activity, the growth of the industry has brought about a growing body of regulatory and supervisory provisions in many countries often implemented and enforced by the central bank or the banking supervisory authorities. Whilst commercialization allowed raising funds for the growth of microfinance, critiques argue that a mission drift has occurred from the social aim of poverty alleviation to the commercial aim of profit maximization (Armendáriz and Szafarz, 2011).

The causality from microfinance to poverty alleviation is based on the assumption of credit market imperfection. Asymmetric information require lenders to perform costly screening and monitoring of borrowers to reduce the problems of adverse selection and moral hazard. Being fixed cost, these transaction costs of conventional banks are prohibitive in small scale lending. Poor persons, who are likely to demand only small amounts of credit, face rationing in the loan market. Hence, in developing countries characterized by high poverty ratios, the majority of people is excluded from financial services and the financial system suffers low outreach. Microfinance thus can help build a more inclusive financial system. Small scale credit can allow the poor to enhance their earning potential in an environment where self-employment is often the only possibility to be economically active and, ideally, to escape poverty (see Duvendack et al., 2011 for a recent review of the empirical evidence).

Given this backdrop the aim of this paper is to examine the trajectories of microfinance in post-Soviet Central Asia, i.e. Kazakhstan, Kyrgyzstan, Tajikistan and Uzbekistan, henceforth CA4. Turkmenistan will only occasionally be touched upon as the availability of information and data is very limited. Though according to the World Bank only Tajikistan and Kyrgyzstan are classified low income countries, poverty is an issue in the other Central Asian countries as well. The trickle-down effect of revenues from exporting primary products is limited and income inequality is high. Likewise outreach of the formal financial system in all countries is low.

Given the prevalence of both poverty and financial exclusion one should expect Central Asia to be a fertile ground for microfinance. The paper thus continues examining closely the microfinance industry in the region. On the country level, the development of various indicators will be studied on the size of the microfinance sector (number of MFI, number of borrowers, size of the loan portfolio), concentration and market power on the supply side, profitability, the quality of the loan portfolio etc. This allows drawing a detailed picture of microfinance in each country as well as comparing the industry between the countries.

\section{Microfinance in Central Asia}

This chapter provides some general socio-economic information about the Central Asian countries, poverty and simple indicators of financial development. The poverty-financial access nexus is then represented in an international setting to support the case for microfinance as a supplement to the formal financial system. The section then provides an overview of microfinance in Central Asia. The development of microfinance in each of the CA4 is reviewed and some key indicators of the demand and the supply side in the market for microcredit will be provided. Moreover the trajectory of the industry in CA4 is put into the context of global trends in microfinance.

In terms of population size post-Soviet Central Asia comprises three small countries, Kyrgyzstan, Tajikistan and Turkmenistan, and two medium-sized countries, Kazakhstan and Uzbekistan (see table 1). Given that the territory of both Kazakhstan and Uzbekistan is huge the population density in all Central Asia is rather low. A 
large share of the population lives in rural areas with limited access to urban infrastructure. The economies are very heterogenous. Kazakhstan is rich in oil and experienced significant economic growth since independence driven by export revenues of oil, minerals and wheat. Turkmenistan, though otherwise a rather closed economy, strongly benefits from export revenues of natural gas. The smaller countries are less blessed with natural ressources. Uzbekistan is a major exporter of cotton the production of which has required giant irrigation projects that are ecologically not sustainable. Kyrgyzstan and Tajikistan have the production and export structure of developing countries lacking natural resources. About one third of the Tajik GNI is earned abroad and enters the country in the form of remittances.

\begin{tabular}{|l|l|l|l|l|}
\hline & Population & GNI / cap & $\begin{array}{l}\text { Average annual } \\
\text { GDP growth }\end{array}$ & $\begin{array}{l}\text { Poverty } \\
\text { headcount ratio }\end{array}$ \\
\hline & (million) & $($ USD-PPP) & $(\%, 2002-12)$ & $(1.25$ USD/day) \\
\hline Kazakhstan & 16.6 & 11,250 & 7.2 & $0.1^{\mathrm{a}}$ \\
\hline Kyrgyzstan & 5.3 & 2,200 & 4.1 & 5.0 \\
\hline Tajikistan & 6.7 & 2,300 & 7.5 & $6.6^{\mathrm{a}}$ \\
\hline Turkmenistan & 4.9 & 8,690 & 12.2 & $24.8^{\mathrm{b}}$ \\
\hline Uzbekistan & 27.3 & 3,420 & 7.7 & --- \\
\hline
\end{tabular}

Table 1: Selected socio-economic and financial indicators of Central Asia Source: Worldbank-World Development Indicators database. Notes: a 2009; b estimation by the Asian Development Bank; $c$ data from the IMF WEO database, own calculations.

The income distribution in all Central Asian countries is hugely uneven. This is most pronounced in Turkmenistan which has a fairly high average income whereas at the same time one fourth of the population lives in extreme poverty. Extreme poverty seems less of an issue in the other four countries though there is a large share of poor people when the national poverty line is considered. In terms of financial development, Kazakhstan, and there most notably the city of Almaty, is often praised the financial center of the region. Indeed the ratio of bank assets to GDP in Kazakhstan reaches the level of some of the Central and East European EU member states that joined in 2004 and 2007 respectively. However the function of the Kazakh banking system has largely been to channel funds borrowed in international capital markets to sectors in need to finance investment, most notably the oil extraction industry and construction. Accordingly, Kazakh banks faced refinancing problems in 2008-09 when the capital markets dried up in the course of the global financial crisis. This and the drop in oil prices was the main spill-over mechanism of the crisis into Kazakhstan. The banking sector of the other Central Asian countries is only to a limited extent developed. Bank assets to GDP ratios are very low. In Kyrgyzstan and Uzbekistan in particular, Kazakh banks own large stakes in the larger commercial banks.

Given the lopsided development of Kazakh banks, financial outreach in the country has been low. Only slightly more than 40 percent of the adult population own a bank account. In the other Central Asian countries these figures are even dramatically lower. Hence both poverty and low financial outreach are problems in Central Asia and the region can be assumed to be fertile ground for the development of microfinance structures. Drawing on a set of 130 countries figure 1 below confirms the assumed poverty-financial access nexus and highlights the location of Central Asian countries. Note that the headcount poverty ratio in this figure relates to the national poverty line which is significantly above USD 1.25 per day. Hence poverty appears to be more of a problem than the figures in table 1 above suggest.

Figure 1 indeed strongly supports the idea that better outreach of the financial system is associated with lower poverty rates. However, it is subject to discussion in which direction the causality works. Proponents of microfinance argue that building more inclusive financial systems causes poverty to decrease as credit allows the poor to become economically active through self-employment, to increase their earnings and ultimately to escape poverty. However, the causality may well work the other way round. A reduction in poverty may increase demand for financial services so that profit maximizing suppliers of financial services ultimately improve outreach to cater the formerly poor. A third possibility is that there is actually no causal link between financial development and poverty but that both variables are driven by the overall level of economic development. The argument would then be that economic growth stimulates financial development and brings down poverty, for instance through the trickle down effect. 


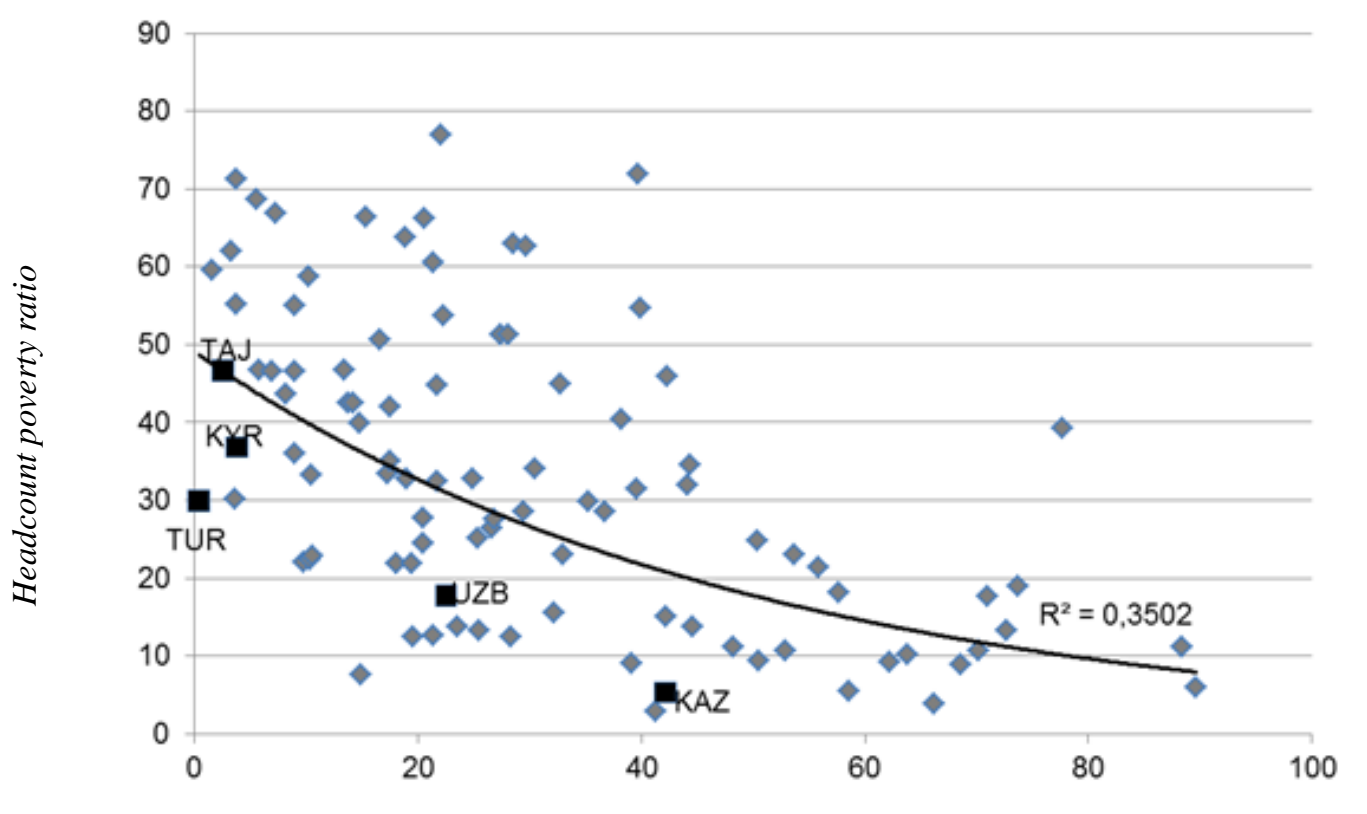

Share of adult population with a bank account (\%)

Figure 1: Poverty and financial inclusion (2011) Source: World Bank - World Development Indicators dataset; Asian Development Bank; CGAP - Global FinDex dataset; own calculations.

Microfinance emerged in Central Asia in the mid-1990s when international donors, most notably the UNDP and USAID, made funds available in the region to finance equity of microfinance institutes.

In Uzbekistan, commercial banks, NGOs and credit unions supply microcredits. More recently pawn shops added to the supply side in the market. Whilst loans extended by commercial banks have the largest share in terms of assets of microcredit providers, credit unions and NGOs account for the largest share of borrowers and thus improve the outreach of the sector. Since its inception in 2006, the state-owned Microcreditbank dominates the sector issuing loans at negative real interest rates.

In Kazakhstan, commercial banks, microlending organisations, NGOs and credit unions offer microloans. Both joint liability group loans and individual loans are supplied. The concentration in the sector is high where the five largest MFIs account for about two third of the aggregate loan portfolio. At the same time there is a relatively large number of registered microcredit suppliers many of which are not operating anymore. When compared to their large populous neighbours, outreach of microfinance in Tajikistan and Kyrgyzstan is much better as indicated by the relatively large numbers of borrowers. These are served by large MFIs and credit unions. Commercial banks play less of a role than in Uzbekistan or Kazakhstan.

\begin{tabular}{|l|l|l|l|l|l|l|l|l|l|}
\hline & \multicolumn{4}{|l}{ Number } & \multicolumn{3}{l|}{ Number of borrowers } & \multicolumn{3}{l|}{ Loan portfolio (mill USD) } \\
\hline & 2007 & 2010 & 2013 & 2007 & 2010 & 2013 & 2007 & 2010 & 2013 \\
\hline Kazakhstan & 745 & 1712 & 1747 & 95,000 & n.a. & n.a. & 291.0 & 369.0 & 502.0 \\
\hline Kyrgyzstan & n.a. & 397 & n.a. & 188,000 & 485,000 & n.a & 112.4 & 195.4 & n.a \\
\hline Tajikistan & n.a. & 123 & 142 & n.a. & 150,000 & 220,000 & 39.0 & 110.0 & 120.0 \\
\hline Uzbekistan & 92 & 209 & n.a. & 21,000 & 104,700 & n.a. & 33.7 & 185.6 & n.a. \\
\hline
\end{tabular}

Table 2: Indicators of microfinance in Central Asia Source: Author's compilation from National Associations of Microfinance Institutes.

In addition to individual countries, the paper looks at microfinance in the entire region as compared to developments in other regions such as South-East Asia, Latin America, and sub-Saharan Africa. A helpful tool to do this is to compare the structure of the aggregate balance sheet of the microfinance industry in Central Asia with other regions. Drawing on a comprehensive database provided by Mixmarket, an international NGO funded by a large number of government bodies and foundations, figure 2 below provides the structure of the aggregate balance sheet of CA4 in 2005 and 2010 respectively.

Assets continue to be dominated by loans. Hence MFI in Central Asia have not diversified into microinsurance. If there are any microinsurance products available, these are supplied through other firms such as insurance companies or state organizations. The structure of the liabilities side changed in the period from 2005 to 2010. In 2010 the leverage of MFI was higher though equity continues to be the most important source of funds. Yet the share of borrowing, largely loans from commercial banks and subsidized loans from international development banks such as the IFC or the KfW, increased to almost 30 percent. Likewise the share 
of deposits tripled although it is still at a meager 10 percent. In particular with respect to the funding structure microfinance in Central Asia differs much from other regions where much of the growth of the sector has been funded by raising additional deposits from microsavers.

2005

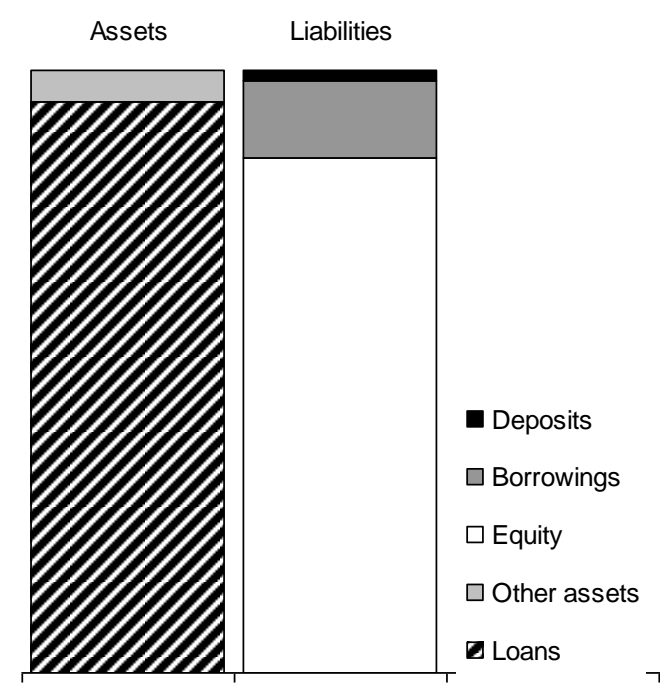

2010

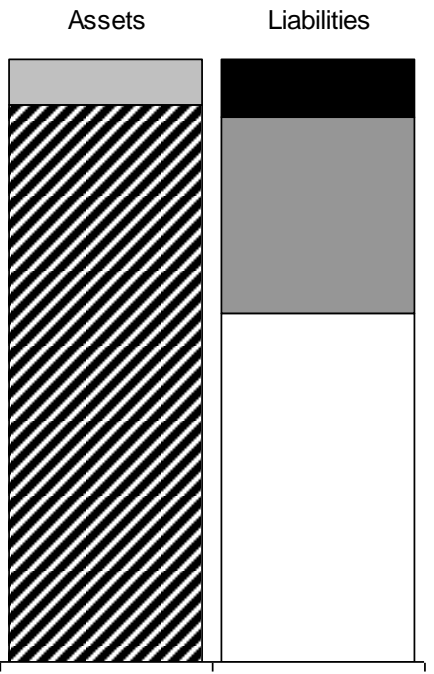

Figure 2: Stylised aggregate balance sheet of MFI in CA4 (2005-2010) Source: Mixmarket; own calculations.

\section{Supervision and regulation of microfinance in Central Asia}

Financial services are among the most strongly regulated industries in the world (Goodhart et al., 1998). The recent global financial crisis sparked a discussion about the quality and the specific nature of the regulatory and supervisory framework (Brunnermeier et al., 2009). As microfinance is an integral yet peculiar part of the financial services industry in developing countries it is reasonable to ask whether the same rationale for regulating MFI applies as for conventional financial intermediaries (see also BSBS, 2010). This section reviews the main arguments for the regulation and supervision of financial services. The rationale behind each argument will be discussed before the transferability to microfinance will be assessed.

Economic arguments for banking regulation and supervision largely rest in market imperfections. Three types of market imperfections are typically emphasized: (i) imperfect competition; (ii) asymmetric or incomplete information; and (iii) externalities.

\subsection{Market power due to imperfect competition}

One of the fundamental insights of welfare economics is that a market in perfect competition maximizes the welfare that accrues from transactions in the market to the society. A deviation from perfect competition and marginal cost pricing is a market imperfection reducing social welfare. Under certain circumstances such as high market entry barriers, the abuse of a dominant position or collusion between different suppliers interventions by a state agency are justified to restore the competitive order or to make the actors in imperfect competition behave as if there were facing competition. In this respect financial markets are not different from goods markets. This is the main argument why it does not require an institutional setting or a specific approach peculiar to the financial services industry. Banks and other intermediaries are subject to the same competition regime as firms operating in other markets. Anti-competitive behaviour is subject to intervention by the authority in charge to implement and enforce competition policy.

In most countries there is an explicit division of power between a banking regulator or supervisor on the one hand and the competition authority on the other hand. While regulators rather tend to restrict competition and to create market entry barriers by means of licensing requirements, competition authorities typically try to remove or reduce this kind of barriers. In general the aim of banking regulation and supervision is to promote financial stability whereas the one of the competition authority is to promote competition. As there may be a trade off between these aims the division of labour between two agencies independent of each other is necessary to avoid a conflict of interest within an agency.

Adverse effects of imperfect competition in microfinance is not an issue. In fact, concentration in the market for microloans is much lower than in the formal financial sector. Severe competition, however, involves risks as well. A recent survey among more than 500 stakeholders in microfinance worldwide identifies challenges from increasing competition among the three major risks the industry is facing (CSFI, 2011). More specifically 
increasing competition may lead to unethical and irresponsible lending practices including usury, deceptive advertising, loan pushing etc. In addition to destabilizing the microfinance industry this puts the main aim of microfinance at risk as the poor could get exploited and overindebted. Indeed, as it will be argued below, concerns related to consumer protection should play a more important role in the regulation of MFI than of commercial banks.

\subsection{Asymmetric information}

In financial transactions at least one party usually possesses information about characteristics of him/herself or of the service provided that are relevant for the transaction and at the same time unknown to the other party. Due to asymmetric information lenders face, first, the problem of adverse selection, i.e. they systematically select borrowers with unfavourable characteristics without getting a fair compensation for the risk associated with those characteristics. Second, asymmetric information may generate moral hazard when the borrower conducts actions that change the risk of the transaction ex post in an undesirable way from the perspective of the lender.

In the loan market the lender is a financial intermediary, say a bank. The bank makes use of a wide array of screening methods to mitigate adverse selection. Moreover collateral, restrictive covenants and other elements of the loan contract aim at aligning the interest of the borrower and the lender. All this obviously incurs transaction costs which financial intermediaries help to reduce due to their expertise, economies of scale and scope. One could even argue that the comparative advantage that financial intermediaries have over markets with respect to transaction costs is the only justification for intermediaries to exist. The crucial aspect here is that neither regulation nor supervision is required to protect the lender from the risks associated with adverse selection and moral hazard.

However, in relation to poor clients conventional mechanisms of screening, monitoring, and contract enforcement fail to bring down transaction costs sufficiently. This is why the poor are considered unbankable. Various mechanisms of microfinance (for details see Armendáriz and Morduch, 2010; Morduch, 1999) provide a more efficient set of institutions in this respect. The most important one is joint liability group lending (JLGL). JLGL has two main effects: (i) it moves, at least partly, transaction costs from the lender to the borrower; and (ii) it reduces transaction costs. Ghatak (2000) shows that JLGL leads to self-selection of borrowers in groups the members of which share similar characteristics with respect to risk. This reduces screening costs of the lender. Stiglitz (1990) demonstrates that JLGL creates incentives for peer monitoring which reduces moral hazard. This reduces monitoring costs of the lender. Besley and Coate (1995) show that peer pressure in JLGL helps enforce the loan contract. This reduces enforcement costs of the lender. The combination of these mechanisms implies that the problems asymmetric information may cause for the lender can be solved without any regulation or supervision. The innovative design of loan contracts provided by microfinance itself is the solution of the problem.

In conventional loan markets the borrower is typically considered the informed party whereas the lender faces the aforementioned problems of adverse selection and moral hazard due to asymmetric information. However, it may be argued that in microfinance there is an additional problem regarding the level of information of the borrower. The vast majority of borrowers in microfinance schemes must be considered financially illiterate largely because of their poor level of education. That means even though information about the nature of the loan or other financial products are available, the borrower does not have sufficient knowledge to fully grasp the implications of the transaction for his or her economic well-being. This makes the poor particularly vulnerable to extortionate behaviour of lenders. Educating the poor to improve their financial literacy would be a measure targeting the roots of the problem most directly. However, there are severe limitations to this when it comes to the practical implementation. This is why a more indirect solution to the problem has been proposed namely the regulation and supervision of MFI to minimize the level of exploitation of the poor (Christen et al., 2003; Davel, 2013).

In the deposit market the individual depositor has imperfect information about the use of his/her funds by the depository institution. However, the rational depositor will not screen and monitor the depository institution for two reasons. First, for small-scale depositors screening and monitoring cost are prohibitive relative to the amount deposited. Second, supervision of the depository institute has the character of a public good for the group of depositors. Other depositors can not be excluded from the discipline imposed on the depository institution due to the supervision of an individual depositor. Thus free riding is rational so that the social level of supervision will be too low. Only a single large depositor could have a sufficiently large incentive to supervise the depository institution individually. In the absence of a single large depositor the government should provide for a regulatory and supervisory framework that makes sure that the depository institution does not engage in excessively risky activities in which the informed depositor would not like to see his funds invested. Accordingly prudential banking regulation largely aims at reducing excessive risk taking and deposit insurance reduces the loss that depositors suffer when the depository institution becomes insolvent.

Indeed one could argue that deposits of the poor require even more protection as they typically constitute the entire wealth of the household which cannot be diversified due to its small size. However, many MFI who accept 
deposits have a dominant depositor typically an international donor such as USAID, KfW etc. These donors have a strong incentive to monitor the behaviour of the MFI. In addition they have the expertise to interpret the information provided by the MFI and the possibility to enforce discipline on the MFI as the donor could threat to withdraw the funds. Thus neither the incentive problem nor the free rider problem of monitoring the depository institution seem to be particularly relevant with respect to MFI.

While the existence of a dominant depositor makes the MFI avoid excessive risk taking it does not set sufficient incentives for the MFI for a sound liquidity management. Once the MFI accepts deposits it is important that the MFI keeps some liquid reserves to make sure smooth conversion of deposits in cash if the depositors wished so. Illiquidity would trigger a domino effect leading to a run of depositors on this bank. Thus the arguments put forward for prudential supervision of banks addressing liquid reserves apply in the same way to MFI.

\subsection{Externalities}

In financial services, it is commonly argued, the failure of an individual institute causes negative externalities on the financial system. If this is true an individual institute tends to accept more risk than desirable from the systemic point of view as part of the cost of failure is external cost to the institute. This would then require some form of regulation which internalizes the external cost. In this respect it is important to think of the spill over mechanism. In which way could the failure of an individual institute be detrimental for other institutes? Generally two spill-over mechanisms are invoked: entanglement of financial intermediaries and demand side network effects. Each of these mechanisms will be briefly described and tested with respect to its transferability to microfinance.

Financial intermediaries operating in the formal financial sector are closely entangled with each other largely via the interbank money market of the economy. Accordingly a critical share of the assets of a bank may be liabilities of another bank. Depending on the size of a bank its insolvency may cause trouble to other banks as well if significant loans in the interbank money market need to be written off. Note that this partly accounts for the too big to fail problem as banks that have a dominant position in the financial system of a country know they will be bailed out by the government because their failure would tear down all the banking system. Thus they tend to accept higher risks than banks that can not count on a bailout.

Obviously this spill over mechanism does not apply to microfinance. First, not being part of the formal financial system MFI do not participate in the interbank money market. And no market exists in the system of microfinance in which liquidity balances are traded. Second, MFI are generally not the counterpart of a claim of any MFI. This is not in line with the underlying idea of microfinance and it is also not common practice.

However, demand side network effects may be a significant source of spill over as some instances of MFI failure proof. Demand side network effects typically root in incomplete information. For instance when a bank faces liquidity or solvency problems, depositors with other banks may be inclined to withdraw their deposits as they do not have sufficient information to assess whether the problem is confined to the individual bank or whether it reflects a problem of the entire banking system. In the worst case this could aggravate to a large scale bank run. There are some arguments for demand side network effects to be particularly severe in microfinance. First, the structure of the balance sheets and the type of risk exposure of different MFI is nearly the same. Hence clients may be even more tempted to interpret trouble in one MFI as a structural problem of the entire sector. This is even more so when MFI do business in the same geographical area where risks of borrowers are closely correlated. For instance a flood or a draught destroying the harvest of farmers in a particular area leads to a surge in loan delinquency or default of all MFI operating in that area. Second, it is reasonable to argue that the assumption of incomplete information applies to clients of MFI even more than to clients of formal banks. Many poor households do not have access to mass media. Depending on the cultural context the main source of information are neighbours, relatives, the assembly of village elders, spiritual leaders of the community etc. This is fruitful ground for rumors to spread.

\subsection{Regulation and supervision of microfinance in Central Asia}

In Uzbekistan, the Law on Credit Unions dates back to mid-2002, the Law on Microfinancing and on Microfinance Organisations to mid-2006 respectively. The Kazakh government of passed the Law on Microlending Organisations in 2006. This law was replaced in December 2012 by the Law on Microfinance Organisations. In Tajikistan the Law on Microfinance Organisations dates back to mid-2012. In Kyrgyzstan the Law on Microfinance Organisations has been in place since 2002. Table 3 below (next page) summarises regulatory and supervisory provisions of the laws and regulations based on these laws that have been in place at the time of writing. 


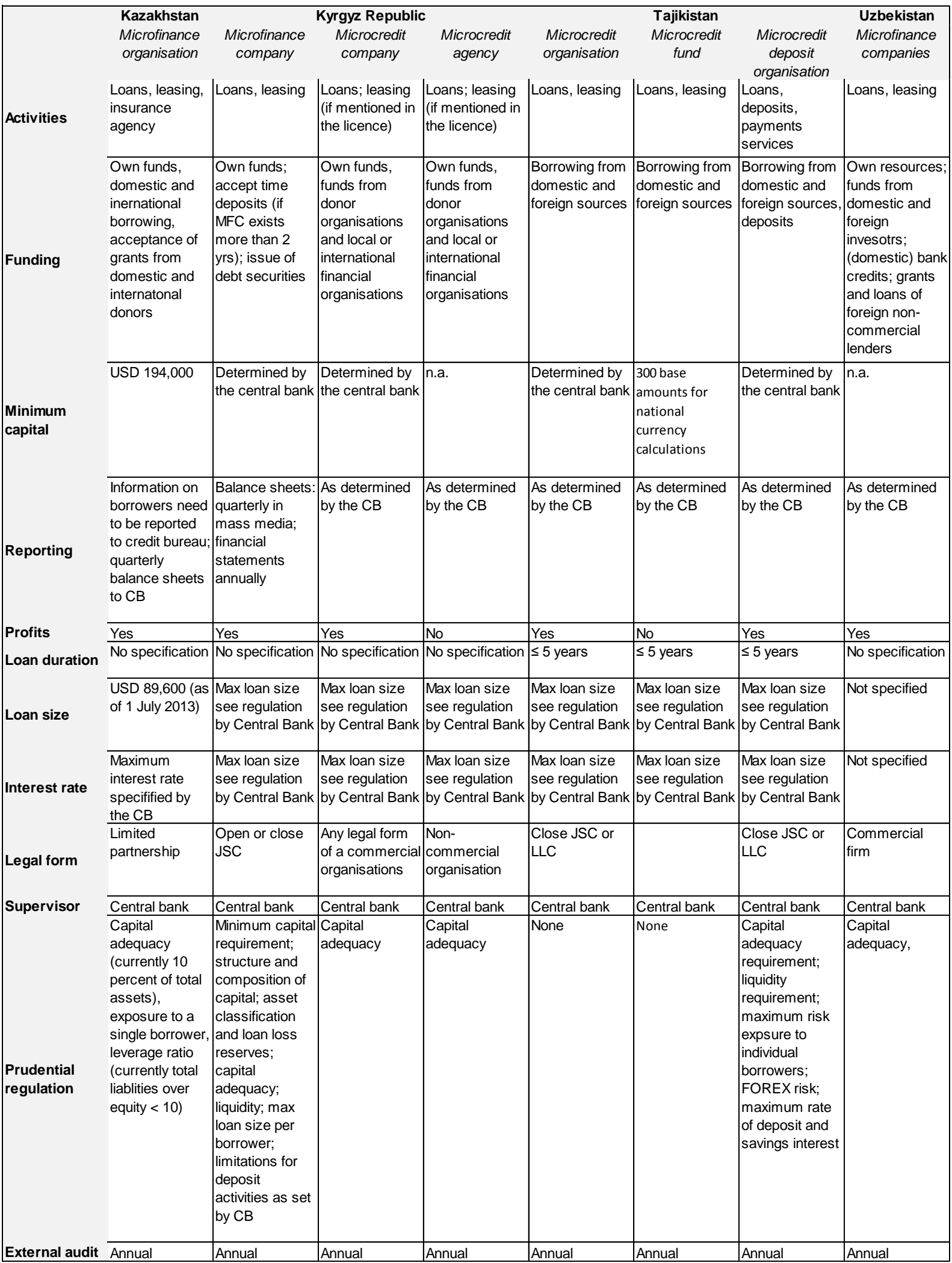

Table 3: Regulation and supervision of MFI in Central Asia Source: Compilation from national laws on microfinance and implementing directives of the central banks of the respective countries.

\section{Non-economic approaches to microfinance in Central Asia}

Whilst poverty is prevalent in Central Asia, though the magnitude of the problem varies regionally, and outreach of the financial system in the region is poor, microfinance does not have the same level of development as in other regions that share the same set of problems. This section briefly discusses three potential non- 
economic reasons for this. These are (i) the political system; (ii) informal institutions; and (iii) religion in Central Asia. Without being exhaustive, the logic behind each factor shall be sketched out below.

\subsection{Autocracy and political economic constraints}

When the Soviet Union demised in 1991, 15 independent and sovereign states emerged. While the Central and East European countries, with the exception of Belarus, adopted democratic political systems characterised by different levels of presidentialism or parliamentiarism, all Central Asian countries ended up being autocratic regimes led by strong presidents (Pomfret, 2006). Arguably the system in Kyrgyzstan is more liberal and more democratic than the other four, not least because the US was more involved in state building. Tajikistan may be considered slightly different either because the way to independence led through a bloody civil war in which different clans battled for control over the state which was at the verge of becoming a failed state during the armed conflict.

Nonetheless in all Central Asian states the presidents managed to install family members, cronies and other loyal persons in nearly all influential positions in politics and business. Political elites and business elites became increasingly congruent. It seems that the main aim of setting policies was to maximize influence and personal wealth of the elites. Constitutional reality has not much limited the possibilities of the political actors to pursue this aim. On the other hand, policies that did not come at the immediate benefit of the elites were procrastinated or not pursued at all. Examples include policies on education, the public system of health care, and social security.

Following this line of reasoning it can be argued that microfinance is less well developed in Central Asia than in most other regions of the world because the ruling elite has not been much interested in developing this sector. Policies to alleviate poverty and to mitigate inequality have not been top of the political agenda. In addition autocratic regimes typically consider the operations international organisations - many of which such as UNDP, GIZ, USAID, are active in providing financial and technical support to MFI - on their territory illegitimate interference with domestic affairs. Likewise non-government organisations are often met with suspicion. Hence, lacking support from the state and from international organisations, grassroot actors were left at their own devices to set up microfinance structures.

\subsection{Peculiar social capital and informal institutions in Central Asia}

Much research on microfinance focuses on the relationship between social capital in a society and microfinance. Two distinct perspectives can be distinguished. On the one hand it has been argued that social capital is an exogenous determinant of the success of microfinance schemes (Karlan, 2007; Karlan et al, 2009). Social capital comes in the form of networks of interpersonal relations generating, for instance, mutual trust. Social capital is a particularly important success factor in joint liability group lending where group members screen and monitor their peers. On the other hand Feigenberg et al. (2010) argue that social capital in endogenous in microfinance as the various institutionalizations of lending schemes foster interpersonal relations and, hence, produce social capital. This argument is occasionally used to justify subsidization of microfinance programs as social capital is a positive externality.

With respect to social capital in Central Asia Collins (2006; 2004) emphasizes the role of clans. Clans are informal organisations based on kinship comprising 500 to 20,000 members. They are often formed on blood relations and ethnity and have a regional core which may or may not branch out. Whilst clan structures are not unique to Central Asia, Collins (2006; 2004) argues that clans gained a particular role in the dynamics of regime change and the formation of new regimes. The benefits of clan membership vary depending on the position in the clan. Clan elites benefit from a loyal network, non-elite members from patronage. In an environment of missing or inefficient formal and informal institutions, the clan potentially fills an institutional vacuum in many areas. With respect to missing or inefficient economic institution, the clans compensate for the missing or malfunctioning labour or capital market. Clans may crowd out alternative political or economic institutions. This crowding out may explain why microfinance is underdeveloped. Even in other countries where clans are not prevalent, research demonstrates that microfinance cannot fully succumb over informal forms of credit allocation such as moneylenders. Clans may have filled the gap of credit allocation in Central Asia impeding the development of alternative, potentially more efficient forms of credit allocation.

\subsection{Islam in Central Asia and microfinance}

Another distinct element of the CA-4 is the distinct role of Islam and religion in general. Microfinance products that are attractive to Muslim believers are still being developed and there seems to be a lack. If this is the case in Central Asia, this may form a demand side constraint for the development of microfinance.

\section{Conclusions}

This paper provided an overview of microfinance in Central Asia. It has been argued that Central Asia, in particular in the southern countries where the outreach of the financial system is low and poverty is a severe problem, is the environment where microfinance can be expected to assume a prominent role. However, a 
detailed overview demonstrated that microfinance in the region has been lagging significantly behind other regions such South Asia or Latin America. Based on a comparative review of the institutional framework, it has been demonstrated that regulatory and supervisory provisions are in place in Central Asia that impede the growth of the sector, whether intended or not. Most notably the prohibition of accepting deposit, microcredit deposit organization in Uzbekistan being the only exception, excludes MFI in Central Asia from a source of funding that developed particularly dynamically in other parts of the developing world. Given the limited scope of financial services that MFI are allowed to supply, reporting requirements and prudential regulation seem overly restrictive in Central Asia. Asking for potential reasons for this, the paper argued that non-economic determinants need to be given particular attention. These may include informal institutions such as the role of clans that can be considered competitors to the development of microfinance structures. Moreover, political economic reasons as well as religious restrictions of Islamic finance have been invoked as potential reasons. More research is needed to substantiate this.

\section{References}

- Armendáriz, Beatriz and Ariane Szafarz. 2011. On Mission Drift in Microfinance Institutions. In: Beatriz Armendáriz and Marc Labie (eds): The Handbook of Microfinance. New York: World Scientific, 341-366.

- Armendáriz, Beatriz and Jonathan Morduch. 2010. The Economics of Microfinance. 2nd ed. Cambridge and London: MIT Press.

- Basel Committee on Banking Supervision (BCBS). 2010. Microfinance Activities and the Core Principles for Effective Banking Supervision. Basel: BIS.

- Besley, Timothy and Stephen Coate. 1995. Group Lending, Repayment Incentives and Social Collateral. American Economic Review, 83(4), 792-810.

- Brunnermeier, Markus K., Andrew Crockett and Charles Goodhart. 2009. The Fundamental Principles of Financial Regulation. London: CEPR.

- Centre for the Study of Financial Innovation (CSFI). 2011. Microfinance Banana Skins 2011 - Losing its Fairy Dust. The CSFI Survey of Microfinance Risk. London and New York: CSFI.

- Christen, Robert Peck, Timothy R. Lyman and Richard Rosenberg. 2003. Microfinance Consensus Guidelines. Guiding Principles on Regulation and Supervision of Microfinance. Washington, DC: CGAP.

- Collins, Kathleen. 2006. Clan Politics and Regime Transition in Central Asia. New York: Cambridge University Press.

- Collins, Kathleen. 2004. The Logic of Clan Politics: Evidence from the Central Asian Trajectories. World Politics, 56(2), 224-261.

- Davel, Gabriel. 2013. Regulatory Options to Curb Debt Stress. CGAP Focus Note 83. Washington, DC: CGAP.

- Duvendack, Maren, Richard Palmer-Jones, James G. Copestake, Lee Hooper, Yoon Loke and Nitya Rao. 2011. What is the Evidence of the Impact of Microfinance on the Well-being of Poor People? London: EPPI-Centre.

- Feigenberg, Benjamin, Erica M. Field and Rohini Pande. 2010. Building Social Capital Through MicroFinance. NBER Working Paper 16018. Washington, DC: NBER.

- Ghatak, Maitreesh. 2000. Screening by the Company You Keep: Joint Liability Lending and the Peer Selection Effect. Economic Journal, 110, 601-631.

- Goodhart, Charles, Philipp Hartmann, David T. Llewellyn, Liliana Rojas-Suarez and Steven Weisbrod. 1998. Financial Regulation: Why, How and Where Now? London: Routledge.

- Karlan, Dean. 2007. Social Connections and Group Banking. Economic Journal, 117 (517), F52-F84.

- Karlan, Dean, M. Mobius, T. Rosenblat and A. Szeidl. 2009. Trust and Social Collateral. Quarterly Journal of Economics, 124, 1307-1361.

- MIX and NAMOCU. 2011. Uzbekistan 2009 Microfinance Analysis and Benchmarking Report. Washington, DC: Microfinance Information Exchange (MIX).

- Morduch, Jonathan. 1999. The Microfinance Promise. Journal of Economic Literature, 37(4), 1569-1614.

- Pomfret, Richard. 2006. The Central Asian Economies Since Independence. Princeton: Princeton University Press.

- Sabi, Manijeh. 2013. Microfinance Institution Activities in Central Asia: A Case Study of Tajikistan and Uzbekistan. Post-Communist Economies, 25(2), 253-266.

- Stiglitz, Joseph E. 1990. Peer Monitoring and Credit Markets. World Bank Economic Review, 4(3), 351366. 